\title{
Analysis of human vulnerability to the extreme rainfall event on 21-22 July 2012 in Beijing, China
}

\author{
J. Liu and S.-Y. Wang \\ Harbin Institute of Technology, School of Management, Harbin, China
}

Correspondence to: J. Liu (liujie198643@163.com)

Received: 11 September 2012 - Published in Nat. Hazards Earth Syst. Sci. Discuss.: Revised: 23 April 2013 - Accepted: 11 June 2013 - Published: 19 November 2013

\begin{abstract}
The aim of this study is to characterize the extreme rainfall event on 21-22 July 2012 in Beijing, and its impact on human vulnerability. Based on the available meteorological and rainfall data from Beijing meteorological stations and Surface Weather Observation Stations, the study draws hourly rainfall maps to simulate the rainfall amount and spatial distribution. Using these maps, this paper provides a quantitative analysis of the impact of the temporal and spatial characteristics of rainfall on the vulnerability of three population groups, according to age, gender and total number of victims. The results of three linear regression models indicate the different effects of extreme rainfall parameters on victims with different characteristics. The analysis of victim data in this extreme rainfall event represents the distribution and characteristics of victims in the eight affected districts, and concludes that the "vulnerable group" are males and adults in this extreme rainfall event. This paper is an initial effort to analyze the impact of an extreme rainfall event on the vulnerability of populations with different characteristics quantitatively, which can be used by stakeholders to prioritize the extreme rainfall event impact issues, and develop contingency plans to address and prevent the human and structural damages caused by the extreme rainfall events.
\end{abstract}

\section{Introduction}

The world is developing and urbanizing at a significant rate (UN-HABITAT, 2003; UNPD, 2007), especially in many developing countries. A negative influence of humans on earth systems, such as rapid urbanization and environmental degradation, is happening on an unprecedented scale (Steffen et al., 2004; MA, 2005), which has induced a "no-analogue" situation of climate change such as sea level rise and changing rainfall patterns. Recent scientific reports (IPCC, 2001; Beniston and Stephenson, 2004; Smith et al., 2004; Mechler et al., 2006) have shown that climate change could generate more extreme climatic events (e.g. hurricanes, floods, extreme rainfall) in many parts of the world in the future. Just in recent years, the increasingly frequent occurence of extreme rainfall disasters that induced flood at regional and global scales (6 April 2010, Rio de Janeiro, Brazil; 20 May 2010, Poland; 15 June 2010, France; 16 June 2010, Bangladesh; 13 August 2011, New York, USA; 12 January 2012, Berlin, Germany; 11 July 2012, Kyushu, Japan) supports the review that climate change is expected to lead to more intense rainfall during 21st century (Groisman et al., 2004; Huntington, 2006; Mechler et al., 2007; Beniston, 2009; Church et al., 2010). These sudden intense rainfall disasters as mentioned above often occur in small areas and have high-intensity rainfall rate with little or no advance warning time to prevent damage, which posts the greatest threat to the natural systems, human life, public health and property (Kelsch et al., 2001; Meehl et al., 2007). Such extreme rainfall events have raised public, political and scientific awareness of extreme rainfall risk (Pelling, 2005; Merz et al., 2007; Dutta et al., 2011). The research of cities' vulnerability to extreme rainfall has been the special focus in many studies (Cislaghi et al., 2005; Bodini and Cossu, 2010). The adaptation and optimized response to the increased incidences of extreme rainfall events are particularly significant and important (Lindley et al., 2006), especially in cities, where high density of populations combined with urbanized land cover can increase the damage of extreme rainfall to human life. 
Vulnerability is the intrinsic characteristic of the hazards' receptors (which can be people, infrastructure, economic activities, etc.). It defines the degree of these receptors' susceptibility to harm from, or inability to cope with hazards (Kaźmierczak and Gina, 2011). In this paper, hazard is defined as the probability of occurrence of a potentially dangerous event in a fixed time range and over a fixed area (UNESCO, 1984). It is related to the type of hazard (determined by the severity of the disaster event). Vulnerability is defined as the conditions determined by physical, social, economic, environmental factors or processes, which increase the susceptibility of a community to the impact of hazards (UN/ISDR 2004). Nowadays, the research of the vulnerability system can be divided into four main components: social vulnerability (Anderson, 2005; Yoon, 2012), economic vulnerability (Fuchs, 2009; Kienberger, 2012), environmental vulnerability (Barnett et al., 2008; Boruff and Cutter, 2007) and physical vulnerability (Luna et al., 2011; Kappes et al., 2012; Totschnig and Fuchs, 2013). Social vulnerability is defined as "the characteristics of a person or group and their situation that influence their capacity to anticipate, cope with, resist and recover from the impact of a natural hazard" (Blaikie et al., 1994; Weichselgartner, 2001; Wisner, 2003). Until recently, experts and scholars have begun to know that the risk of disasters may be increased by the surrounding environment of the disasters. With the rapid development of cities and many more people migrating to cities, the city becomes more susceptible to natural disasters and man-made disasters. So the research of social vulnerability that can identify the socio-economic conditions of individuals (e.g. age, race, health, income, employment) related to a particular risk and predict the vulnerability of specific groups of affected people, will improve the mitigation of negative disasters (Hewitt, 1997; Basher and Briceño, 2005). Human vulnerability is defined as the characteristics of individuals in terms of their capacity to anticipate, cope with, resist and recover from the shocks and stresses of natural disaster (Blaikie et al., 1994). Nowadays, it is increasingly being seen as a key step in measuring the social vulnerability towards effective risk reduction and promotion of a culture of disaster resilience (Blaikie, 2006). According to Turner et al. (2003), human vulnerability depends on three main factors: the level of exposure, the sensitivity of an individual or system and the ability to cope with an event. In recent decades, the research on human vulnerability has covered three aspects: human exposure (whether or not people are in the affected area of disasters), human susceptibility (the probability and extent of humans to be affected by disasters), and human resilience (the ability of humans to recover from disasters) (Bosher et al., 2007). Just in the research of human exposure, Cutter et al. (2000) proposes that human exposure is referred to the location of people, which can increase or reduce the contact between people and natural disasters. She illustrates that the fatality rate resulting from a flood event is highly influenced by three major factors: the number of people occupying the flood plain, which is also called population at risk; the amount of warning that is provided to the people exposed to dangerous flooding; and the severity level to the people. Honghai and Altinakar (2011) maintain that loss-of-life computation should consider many uncertainty factors in flood severity, warning time, population at risk, and fatality rate. Within the research of human susceptibility, some studies show that human susceptibility is the negative definition of vulnerability, which refers to the degree or extent of a community to be affected by disasters and often expressed by the depth-damage relationships (UN/ISDR, 2004; ADPC, 2005; Thywissen, 2006; Meyer et al., 2009). For example, the susceptibility of individuals to flood hazards is dependent on several factors, such as the geographical location, socio-economic and cultural conditions, political and institutional structures as well as coping and adaptive capacity; these factors differentiate the impact of flood hazards on people and human systems (Wisner, 2003; Barroca et al., 2006). In the research of human resilience, some studies show that human resilience is the positive definition of vulnerability, which refers to the people's capacity to withstand or recover from the damaging effect of extreme loads (Burton et al., 1993; Kelly and Adger, 2000; Walker et al., 2002; Cardona, 2005). The risk awareness of people is increasingly seen as a crucial factor in the promotion of human resilience (UN/ISDR, 2004; McEntire, 2005). These studies include the research by the NATO Advanced Study Institute on "Coping with Flash Floods" (Montz and Gruntfestb, 2002), the research by Miceli on "the perception of risk" (Miceli et al., 2008), the research by Ibidun on "the awareness and preparedness of affected people" (Ibidun, 2011), and the research by Creutin and Borga on "the social response time for different social actions" (Creutin and Borga, 2003).

In the research on human vulnerability above, more specific studies have focused on the qualitative research of human vulnerability, lacking the detailed quantitative analysis of the impact of physical characteristics of extreme rainfall event on human vulnerability. So this paper is a first attempt to combine the physical distribution and characteristics of extreme rainfall with victims of different characteristics (age and gender) to analyze the impact of the hydrometeorological conditions on human vulnerability of different types of populations in this extreme rainfall event. According to Turner et al. (2003), the level of human vulnerability is mainly determined by the physical characteristics of people. The vulnerability of people to act in an extreme rainfall event could be negatively affected by their age (Kaźmierczak and Gina, 2011). Gender are often the most pertinent factor in differentiated vulnerabilities that are exacerbated through disaster processes (Enarson and Morrow, 1998; Cannon, 2002). Reports from Sri Lanka and India suggest that more than $30 \%$ of victims killed by the tsunami of 2004 were children (Rohde, 2005). In the great Hanshin earthquake in 1995, more than half of the 6000 killed were over $60 \mathrm{yr}$ of age (Wisner and Blaikie, 1994). So in this paper, 


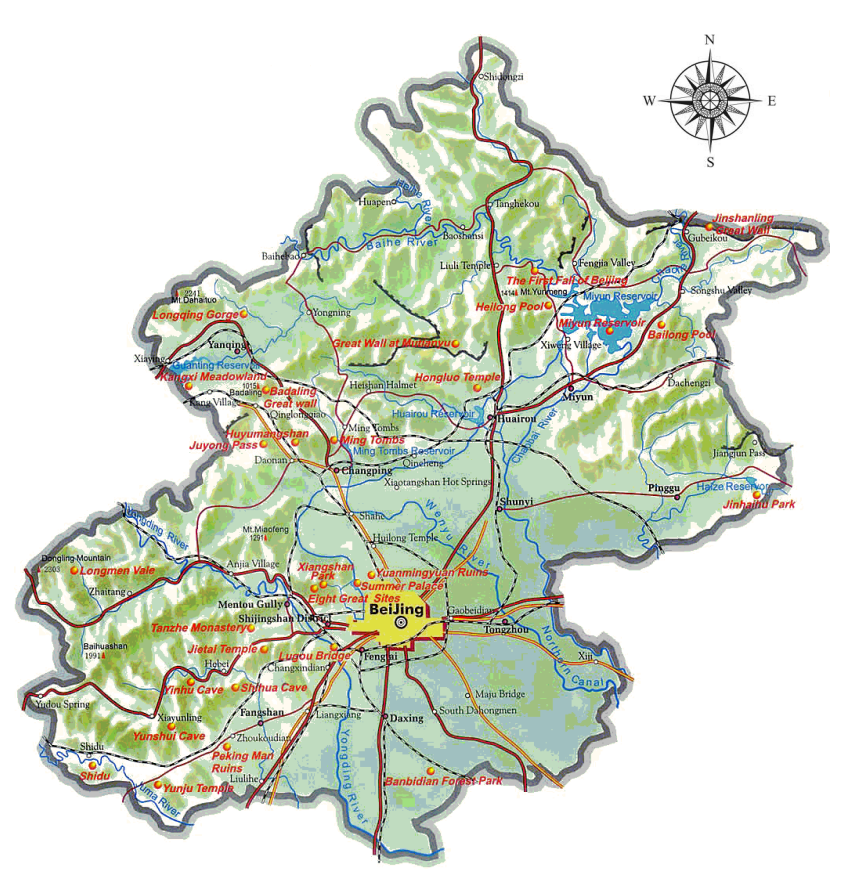

Fig. 1. Topographic map of Beijing.

using the database of victims that died in the extreme rainfall event in the eight affected districts of Beijing, we conduct the statistical analysis of their characteristics, including their gender, age, the causes of death, the distribution and location of victims in the eight affected regions. Combined with the rainfall distribution and characteristics of rainfall in the eight affected districts of Beijing, we select three key extreme rainfall parameters (response time, rainfall event and rainfall duration) to estimate the degree of risk of this extreme rainfall event. Adopting the linear regression analysis approach, we estimate the effects of each extreme rainfall parameter on victims with different characteristics (e.g. gender, age). These results can then help us learn which types of individuals are at highest risk of extreme rainfall event, and the key extreme rainfall parameters for affecting the human vulnerability of different types of populations in the extreme rainfall event.

\section{Study area}

Beijing (latitude $39^{\circ} 54^{\prime} \mathrm{N}$ and longitude $116^{\circ} 23^{\prime} \mathrm{E}$ ), located in northeast China, covers a total area of $16807.8 \mathrm{~km}^{2}$ and has a population of 14.93 million people. It is the nation's political, economic, cultural and educational center as well as China's most important center for international trade and communications. Geographically, Beijing is located at the northern tip of the North China Plain $(102 \mathrm{~km}$ west of Bo Hai Sea), near the meeting point of the Xishan and Yanshan mountains. The city itself lies on low and flat land, with

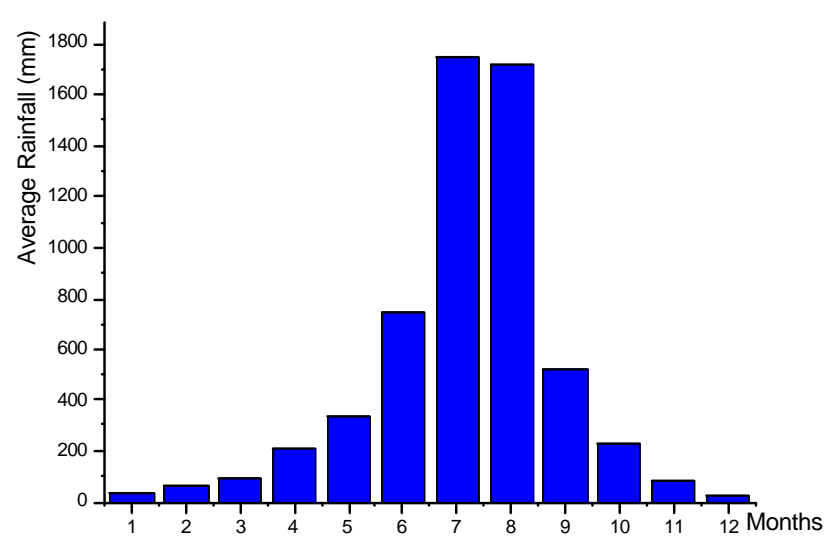

Fig. 2. Average monthly rainfall data series during 1951-2010 in Beijing.

elevation generally between $40-60 \mathrm{~m}$ a.s.l., and opens to the east and south. In Beijing, mountains surround the city from the southwest to the northeast and reach elevations of over $2000 \mathrm{~m}$. The terrain of Beijing is roughly $38 \%$ flat and $62 \%$ mountainous. Several major rivers, including the Yongding, Chaobai and Wenyu flow through Beijing Municipality. They originate on the Inner Mongolia Plateau, cut through the mountains west and north of the city, and eventually flow into the Bohai Sea. Figure 1 shows the topographic map of Beijing.

The city's climate is a rather dry, monsoon-influenced humid continental climate (Fig. 2), characterized by hot, humid summers due to the East Asian monsoon, and generally cold, windy, dry winters that reflect the influence of the vast Siberian anticyclone. Most of Beijing's rainfall falls in the summer months (July and August) due to the Asian Monsoon and Maiu Front, which is most likely to lead to the occurrence of the extreme rainfall events. Beijing Meteorological Observatory (2011) indicates that increased frequency and magnitude of extreme rainfall events have occurred since 1998; even in the past $5 \mathrm{yr}$, the extreme rainfall events which cause local floodings occur in Beijing almost every year (e.g., 4 July 2008, 23 July 2009, 13 June 2010, 23 June 2011). The rainfall of these events present the characteristics of highintensity, locality and short time duration.

Besides the increased frequency of extreme rainfall events, urban development is a large creator of the increasing vulnerability of city residents (Adelekan, 2000). The total population of Beijing increased from 8.71 million in 1978 to 19.61 million in 2010 (Fig. 3). The rapid population growth will increase the probability of human death and injury during a extreme rainfall event (Fernando, 2007). The percentage of the urban population increased from $54.96 \%$ in 1978 to $85.96 \%$ in 2010 . More migrants and new residents that are unaware of the risk of natural disasters and have difficulty in accessing and interpreting important information (Pfister, 2002) increase the number of the socially vulnerable 


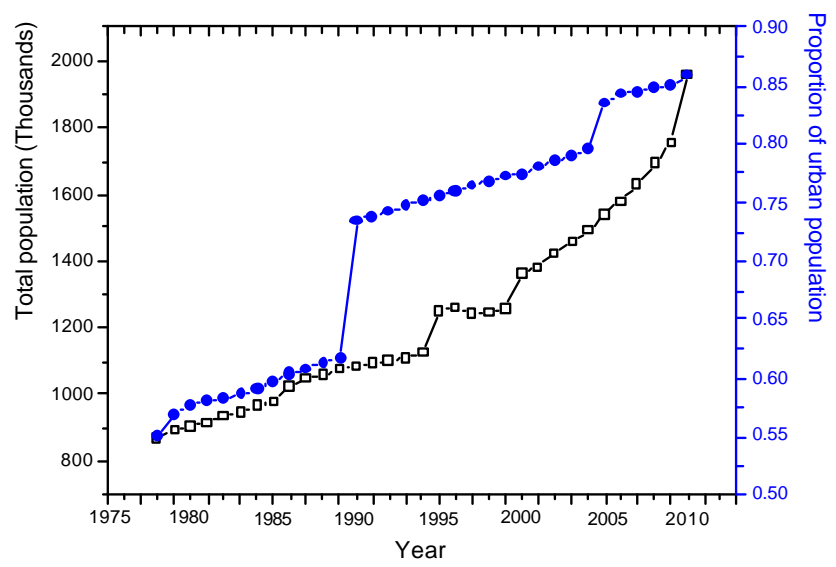

Fig. 3. The data series of the total population and the proportion of urban population in Beijing during 1978-2010.

population of Beijing. Table 1 shows the distribution of population and land area in the each district of Beijing in 2012 (before the extreme rainfall event).

1. Children are defined as persons younger than $18 \mathrm{yr}$ old.

2. Adults are defined as persons aged between 18 and 49 .

3. Elderly people are defined as persons older than $50 \mathrm{yr}$ old.

\section{Data and method}

On 21-22 July 2012, Beijing was hit by a 1-in-60 yr event. The extreme rainfall began at 10:00 UTC on 21 July, and lasted nearly $16 \mathrm{~h}$. From the data announced by the China Meteorological Administration, in less than $24 \mathrm{~h}$, the average rainfall of the whole city is more than $170 \mathrm{~mm}$. In the city areas, the average rainfall was more than $225 \mathrm{~mm}$. Especially in Fangshan District, the maximum rainfall accumulated in $24 \mathrm{~h}$ is $460 \mathrm{~mm}$, a 1 -in-500 yr event. This extreme rainfall caused floods and mudslides in Fangshan District. It was the deadliest hydro-meteorological catastrophe in Beijing since 1951. This extreme rainfall event took 77 human lives, created 1.9 million homeless, and damaged many aspects of the infrastructure including houses, roads, bridges, drainages, and electricity poles. The economic losses of agricultural production was estimated to be 450 million yuan over the affected area of $16000 \mathrm{~km}^{2}$.

\subsection{Data}

\subsubsection{Victims data}

On 21-22 July 2012, 77 persons were killed in the extreme rainfall event in the eight affected districts of Beijing (only 60 victims' specific information was announced by the Government of China). Data of victims were collected

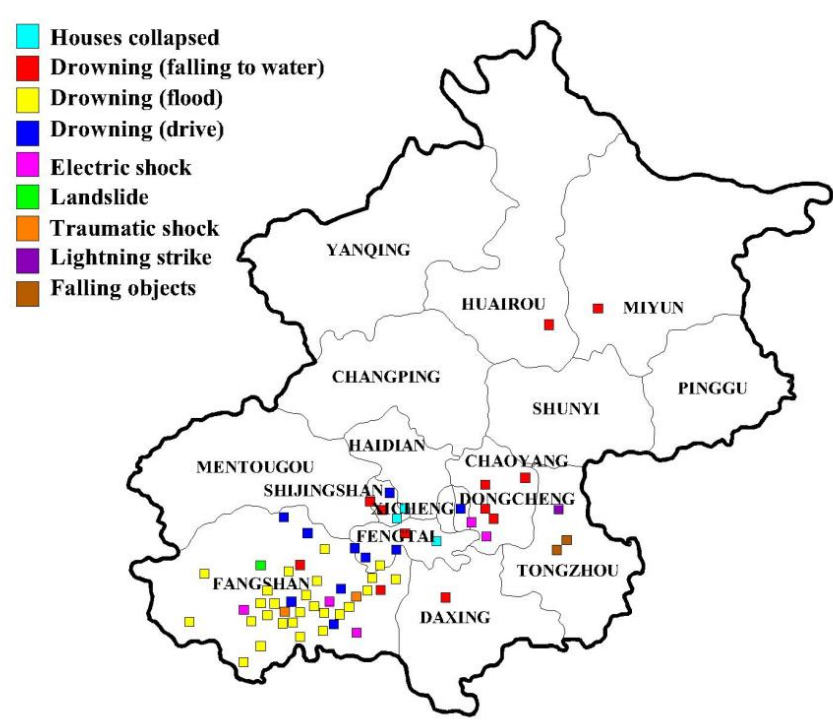

Fig. 4. Distribution of victims in the extreme rainfall event.

by combining different sources. The list of victims obtained from a report published by the National Flood Control and Drought Relief Agency. The detail characteristics of victims include gender, age, the cause of death, the precise time and location of death gathered from the newspapers following the extreme rainfall event, the municipality and rescue services. In addition to the available database, field surveys and interviews were carried out to obtain more local information about the characteristics of victims in the extreme rainfall event. Table 2 and Fig. 4 show a summary data of the characteristics and distribution of the victims of this extreme rainfall event.

\subsection{Rainfall data}

To analyze the rainfall variations of these extreme rainfall events that occurred in Beijing, daily and hourly rainfall data are readily available from 48 rainfall gauge stations in Beijing. The Beijing meteorological stations are used to obtain rainfall data in the study area. In this study, the rainfall data are mainly provided by the Surface Weather Observation Stations. Other detailed climatic data are collected from the "National Meteorological Information Center", various documented/published reports, government website databases and sources (e.g. newspaper, broadcasting). Combined with these rainfall data above, in this paper, we use the TPS (thin plate spline) method to estimate the rainfall process of this extreme rainfall event on 21 July 2012, between 09:00 UTC and 21:00 UTC. Thin plate splines (TPS) were introduced to geometric design by Duchon (Duchon, 1976). Recent comparisons with geostatistical (kriging) methods, with which splines share close formal connections, have been presented by Hutchinson (1993), Hutchinson and Gessler (1994) and Lasletta (1994). Then we use GIS to reconstruct the rainfall 
Table 1. The distribution of population and land area in the eight affected districts in 2012.

\begin{tabular}{|c|c|c|c|c|c|c|c|}
\hline District & $\begin{array}{l}\text { Land } \\
\text { Area } \\
\left(\mathrm{km}^{2}\right)\end{array}$ & $\begin{array}{r}\text { Total Population } \\
\text { Population } \\
\text { (Ten thousand) }\end{array}$ & $\begin{array}{r}\text { The number } \\
\text { of males } \\
\text { (Ten thousand) }\end{array}$ & $\begin{array}{r}\text { The number } \\
\text { of females } \\
\text { (Ten thousand) }\end{array}$ & $\begin{array}{r}\text { The number } \\
\text { of children } \\
\text { (Ten thousand) }\end{array}$ & $\begin{array}{r}\text { The number } \\
\text { of adults } \\
\text { (Ten thousand) }\end{array}$ & $\begin{array}{l}\text { The number of } \\
\text { elderly people } \\
\text { (Ten thousand) }\end{array}$ \\
\hline Xicheng & 31.62 & 124.0 & 61.7 & 62.3 & 10.7 & 95.9 & 17.4 \\
\hline Chaoyang & 455.08 & 365.8 & 188.8 & 177.5 & 30 & 304.2 & 31.6 \\
\hline Fengtai & 305.80 & 217 & 110.4 & 106.6 & 20.6 & 176.6 & 19.8 \\
\hline Fangshan & 1989.54 & 96.7 & 49.5 & 47.2 & 10.1 & 77.9 & 8.7 \\
\hline Tongzhou & 906.28 & 125 & 64.7 & 60.3 & 11.3 & 103.7 & 10 \\
\hline Shunyi & 1019.89 & 91.5 & 48.3 & 43.2 & 8.1 & 76.4 & 7.0 \\
\hline Changping & 1343.54 & 173.8 & 92.1 & 81.7 & 16.1 & 146.8 & 10.9 \\
\hline Daxing & 1036.32 & 142.9 & 77.0 & 65.9 & 15.2 & 118.5 & 9.2 \\
\hline Yanqing & 1993.75 & 31.9 & 16.3 & 15.6 & 3.8 & 25.1 & 3.0 \\
\hline
\end{tabular}

process and build hourly rainfall maps (an approximated horizontal resolution of $0.5^{\circ} \times 0.5^{\circ}$ ) of this extreme rainfall event (Fig. 5).

\subsection{Linear regression analysis of the effects of the extreme rainfall parameters on the human vulnera- bility of different types of populations}

Researchers have emphasized that characteristics of the extreme rainfall event are important parameters, affecting the distribution of population at risk significantly (Machefert and Dise, 2004). Isabelle et al. (2008) proposes that the first step in identifying human vulnerability in different disaster situations is to better understand the circumstances of the accidents resulting from such events. So in this paper, we use response time, rainfall event and rainfall duration as parameters to describe the temporal and spatial characteristics of this extreme rainfall event. Table 3 shows the data of these extreme rainfall parameters of the eight affected districts.

\subsubsection{Response time}

Hydrologists define response time as the reaction time people have after an extreme rainfall event occurs, which is represented by the time between the occurrence of the extreme rainfall to the arrival of the rainfall peak. The extreme rainfall event that occurs in a small catchment with a response time shorter than $1 \mathrm{~h}$ appears to be more dangerous, and it is often said that warnings for these events are useless (Isabelle et al., 2008). In this paper, we use the time that the accumulative rainfall reached $50 \mathrm{~mm}$ or $100 \mathrm{~mm}$ in the initial stage of an extreme rainfall event to define response time. In China, a rainstorm warning can be divided into four levels on the basis of rainfall: the blue rainstorm warning (the accumulative rainfall will be more than $50 \mathrm{~mm}$ rainfall in twelve hours, or has reached more than $50 \mathrm{~mm}$ rainfall and is likely to continue), the yellow rainstorm warning (the accumulative rainfall will be more than $50 \mathrm{~mm}$ rainfall in six hours, or has reached more than $50 \mathrm{~mm}$ rainfall and is likely to continue), the orange rainstorm warning (the accumulative rainfall will be more than $50 \mathrm{~mm}$ rainfall in three hours, or has reached more than $50 \mathrm{~mm}$ rainfall and is likely to continue), and the red rainstorm warning (the accumulative rainfall will be more than $100 \mathrm{~mm}$ rainfall in three hours, or has reached more than $100 \mathrm{~mm}$ rainfall and is likely to continue). In this paper, we use two indexes to estimate response time for people and government after an extreme rainfall event occurred: $\mathrm{TP}_{50}$ denotes the time the accumulative rainfall reached $50 \mathrm{~mm}$. $\mathrm{TP}_{100}$ denotes the time the accumulative rainfall reached $100 \mathrm{~mm}$.

\subsubsection{Rainfall event}

The rainfall event can be used as a key indicator to determine and forecast extreme rainfall severity; it implies that the extreme rainfall event may occur more severely due to the increasing trend of the heavy rainfall intensity. People tend to become victims at particular locations where rainfall intensity is higher than the resistance offered by a human body, or even induce local flooding. In this paper, we use three indexes to represent the rainfall events of the extreme rainfall event: TP denotes the total rainfall of the affected areas; MHP denotes the maximum hourly rainfall of the affected areas; and AHP denotes the average hourly rainfall of the affected areas. 
Table 2. Summary of victims' characteristics from the extreme rainfall event in Beijing on 21-22 July 2012.

\begin{tabular}{|c|c|c|c|c|}
\hline District & Gender & Age & Death circumstances & The cause of death \\
\hline \multirow{6}{*}{ Chaoyang District (6 Persons) } & $\mathrm{F}$ & 22 & In the village (Outside home) & Drowning (Falling into water) \\
\hline & M & 36 & In the village (Outside home) & Electric shock \\
\hline & M & 24 & The basement of community & Electric shock \\
\hline & M & 17 & On the lawn & Drowning (Falling into water) \\
\hline & M & 42 & Under the bridge & Drowning (Falling into water) \\
\hline & M & 17 & In the village (Outside home) & Drowning (Falling into water) \\
\hline \multirow{5}{*}{ Fengtai District (5 Persons) } & M & 39 & On the river bank & Houses collapsed \\
\hline & $\mathrm{F}$ & 33 & The basement of community & Drowning (Falling into water) \\
\hline & $\mathrm{F}$ & 43 & On the highway & Drowning (Driving) \\
\hline & $\mathrm{F}$ & 41 & On the highway & Drowning (Driving) \\
\hline & $\mathrm{F}$ & 27 & On the highway & Drowning (Driving) \\
\hline \multirow{5}{*}{ Shijingshan District (5 Persons) } & M & 15 & On the river bank & Drowning (Falling into water) \\
\hline & M & 40 & At home & Houses collapsed \\
\hline & $\mathrm{F}$ & 40 & At home & Houses collapsed \\
\hline & M & 49 & On the river bank & Drowning (Driving) \\
\hline & $\mathrm{F}$ & 22 & On the street & Drowning (Falling into water) \\
\hline Daxing District (1 Person) & M & 44 & Under the bridge & Drowning (Falling into water) \\
\hline \multirow{3}{*}{ Tongzhou District (3 Persons) } & M & 63 & In the primary school & Falling objects \\
\hline & M & 40 & In the primary school & Falling objects \\
\hline & M & 45 & In the primary school & Lightning strike \\
\hline \multirow{2}{*}{$\begin{array}{l}\text { Huairou District (1 Person) } \\
\text { Miyun County (1 Person) }\end{array}$} & M & 21 & Under the bridge & Drowning (Falling into water) \\
\hline & M & 30 & At front of the hospital & Drowning (Falling into water) \\
\hline \multirow{38}{*}{ Fangshan District (38 Persons) } & M & 38 & In the village (Outside home) & Electric shock \\
\hline & M & 52 & At home & Electric shock \\
\hline & M & 32 & At home & Electric shock \\
\hline & M & 22 & In the village (Outside home) & Traumatic shock \\
\hline & M & 49 & On the river bank & Traumatic shock \\
\hline & $\mathrm{F}$ & 23 & In the village (Outside home) & Drowning (Flood) \\
\hline & M & 52 & In the village (Outside home) & Drowning (Driving) \\
\hline & M & 42 & On farms & Drowning (Driving) \\
\hline & $\mathrm{F}$ & 26 & At the gas station & Drowning (Flood) \\
\hline & M & 44 & In the district & Drowning (Flood) \\
\hline & M & 5 & In the village (Outside home) & Drowning (Flood) \\
\hline & $\mathrm{F}$ & 24 & In the village (Outside home) & Drowning (Flood) \\
\hline & $\mathrm{F}$ & 30 & In the village (Outside home) & Drowning (Flood) \\
\hline & $\mathrm{F}$ & 62 & In the village (Outside home) & Drowning (Flood) \\
\hline & M & 20 & In the village (Outside home) & Drowning (Flood) \\
\hline & $\mathrm{F}$ & 44 & In the village (Outside home) & Drowning (Flood) \\
\hline & M & 42 & On the river bank & Drowning (Flood) \\
\hline & M & 59 & In the village (Outside home) & Drowning (Flood) \\
\hline & $\mathrm{F}$ & 55 & In the village (Outside home) & Drowning (Flood) \\
\hline & M & 30 & In the village (Outside home) & Drowning (Driving) \\
\hline & $\mathrm{F}$ & 19 & In the village (Outside home) & Drowning (Flood) \\
\hline & M & 10 & In the village (Outside home) & Drowning (Flood) \\
\hline & $\mathrm{F}$ & 55 & In the village (Outside home) & Drowning (Flood) \\
\hline & M & 80 & In the village (Outside home) & Drowning (Flood) \\
\hline & M & 38 & In the village (Outside home) & Drowning (Flood) \\
\hline & $\mathrm{F}$ & 40 & In the village (Outside home) & Drowning (Flood) \\
\hline & $\mathrm{F}$ & 17 & In the village & Drowning (Flood) \\
\hline & $\mathrm{F}$ & 62 & In farms & Drowning (Flood) \\
\hline & $\mathrm{F}$ & 36 & In the village (Outside home) & Drowning (Flood) \\
\hline & M & 55 & In the army & Landslide \\
\hline & $\mathrm{F}$ & 30 & In the village (Outside home) & Drowning (Flood) \\
\hline & $\mathrm{F}$ & 1 & In the village (Outside home) & Drowning (Flood) \\
\hline & M & 66 & In the village (Outside home) & Drowning (Flood) \\
\hline & $\mathrm{F}$ & 41 & In the village (Outside home) & Drowning (Flood) \\
\hline & M & 49 & In the village (Outside home) & Drowning (Driving) \\
\hline & $\mathrm{F}$ & 54 & In the village (Outside home) & Drowning (Driving) \\
\hline & $\mathrm{F}$ & 43 & In the village (Outside home) & Drowning (Driving) \\
\hline & M & 30 & In the village (Outside home) & Drowning (Driving) \\
\hline
\end{tabular}



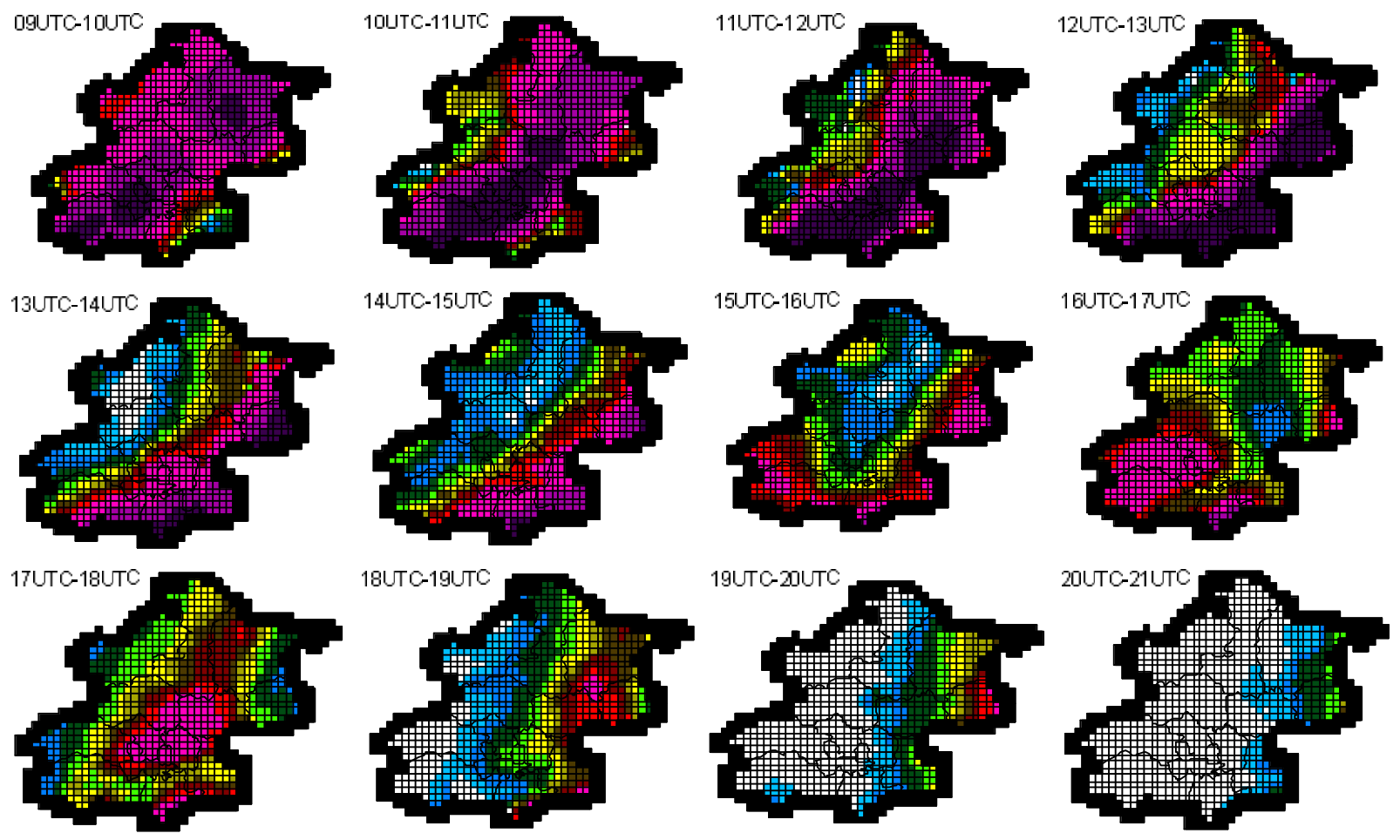

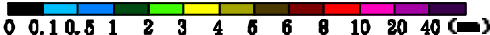

Fig. 5. Rainfall from 09:00 UTC to 21:00 UTC on 21 July 2012 in Beijing.

\subsubsection{Rainfall duration}

Linnekampa et al. (2011) indicates that the different duration of high-intensity rainfall in different areas can substantially impact a human's ability to cope and recover. Flash floods are predominantly caused by the heavy rainfall with short duration, occurring locally. Therefore, such floods are difficult to forecast, warn against and prepare for (Falconer et al., 2009). In this paper, we use three indexes to represent the duration of three different levels rainfall intensity of the extreme rainfall event: $\mathrm{DP}_{10}$ denoted the duration of hourly rainfall above $10 \mathrm{~mm} \mathrm{~h}^{-1} ; \mathrm{DP}_{20}$ denoted the duration of hourly rainfall above $20 \mathrm{~mm} \mathrm{~h}^{-1}$; and $\mathrm{DP}_{30}$ denoted the duration of hourly rainfall above $30 \mathrm{~mm} \mathrm{~h}^{-1}$.

In order to analyze the human vulnerability of populations with different characteristics, the victims are classified by gender (male or female) and age (child $\langle$ younger than 18$\rangle$, adult $<$ aged between 18 and 49>, or elderly people < older than $50>$ ). Regarding human vulnerability, in this paper our major theoretical hypothesis is that higher levels of human vulnerability result from more victims due to extreme rainfall events. So we use the number of different types of victims to represent the human vulnerability of populations with different characteristics.
In this paper, a linear regression analysis is used to predict the effect of extreme rainfall parameters on human vulnerability and find the decisive indicator which has the significant influence on human vulnerability. In statistics, regression analysis is a statistical technique for estimating the relationships among variables. It includes many techniques for modeling and analyzing several variables, when the focus is on the relationship between a dependent variable and one or more independent variables. More specifically, regression analysis helps one understand how the typical value of the dependent variable changes when any one of the independent variables is varied, while the other independent variables are held fixed. Regression analysis is widely used for prediction and forecasting, where its use has substantial overlap with the field of machine learning. Regression analysis is also used to understand which among the independent variables are related to the dependent variable, and to explore the forms of these relationships.

\section{Results}

\subsection{Analysis of the rainfall characteristics}

The twelve maps (Fig. 5) illustrate spatial distribution of the rainfall event on 21 July, between 09:00 and 21:00 UTC. From 09:00 to 10:00 UTC, the high-intensity rainfall began 
Table 3. Data of the extreme rainfall parameters of the eight affected districts on 21-22 July 2012 in Beijing.

\begin{tabular}{lrrrrrrrr}
\hline \multirow{2}{*}{ District } & \multicolumn{3}{c}{ Response Time } & \multicolumn{3}{c}{ Rainfall Event } & \multicolumn{3}{c}{ Rainfall Duration } \\
\cline { 2 - 9 } & $\begin{array}{rrrrr}\mathrm{TP}_{50} \\
(\mathrm{~h})\end{array}$ & $\begin{array}{r}\mathrm{TP}_{100} \\
(\mathrm{~h})\end{array}$ & $\begin{array}{r}\mathrm{TP} \\
(\mathrm{mm})\end{array}$ & $\begin{array}{r}\mathrm{MHP} \\
(\mathrm{mm})\end{array}$ & $\begin{array}{r}\mathrm{AHP} \\
(\mathrm{mm})\end{array}$ & $\begin{array}{r}\mathrm{DP}_{10} \\
(\mathrm{~h})\end{array}$ & $\begin{array}{r}\mathrm{DP}_{20} \\
(\mathrm{~h})\end{array}$ & $\begin{array}{r}\mathrm{DP}_{30} \\
(\mathrm{~h})\end{array}$ \\
\hline Fangshan & 1.34 & 2.79 & 167.03 & 38.69 & 15.18 & 4 & 4 & 3 \\
Chaoyang & 1.82 & 2.86 & 181.97 & 50 & 16.54 & 5 & 3 & 2 \\
Fengtai & 1.25 & 2.25 & 203.62 & 50 & 22.40 & 5 & 4 & 3 \\
Shijingshan & 1 & 2 & 182.35 & 50 & 18.24 & 4 & 3 & 2 \\
Daxing & 2.52 & 3.73 & 214.16 & 48.82 & 17.85 & 8 & 4 & 3 \\
Tongzhou & 4.16 & 4.35 & 162.88 & 48.42 & 13.57 & 5 & 3 & 1 \\
Huairou & 2.84 & 21 & 68.62 & 20.01 & 5.72 & 3 & 1 & 0 \\
Miyun & 1.63 & 8.78 & 110.63 & 33.16 & 8.51 & 3 & 2 & 1 \\
\hline
\end{tabular}

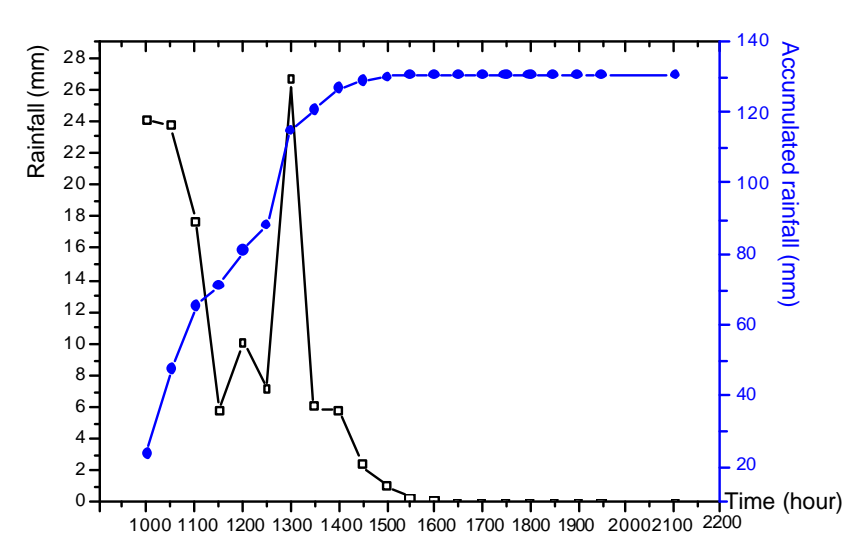

Fig. 6. Hourly and accumulated rainfall of Beijing between 09:00 UTC and 21:00 UTC on 21-22 July 2012.

at the southwest and northeast regions of Beijing, including the districts of Miyun, Fangshan and Fengtai. These districts are all located at the foot of Taihang mountain, which was affected by the southwesterly airstream and terrain and lifted a lot of warm and humid air to condense into the extreme rainfall. In the following two hours, a more intense rainfall moved from northeast into southwest regions, the rainfall rate of most southwest regions (including Shunyi, Chaoyang, Fengtai, Fangshan) increased (up to $40 \mathrm{~mm} \mathrm{~h}^{-1}$ ) and was more concentrated over some low lying plains, which caused the local flooding event. From 12:00 to $16: 00 \mathrm{UTC}$, the rainfall continued moving into the southeast regions of Beijing, and the rainfall rate began to decrease. Up to 16:00 UTC, the second rainfall peak occurred in the southwest and the central regions in Beijing, including Fangshan, Mentougou, Chaoyang, Haidian, Shijingshan and Fengtai districts. After that, the extreme rainfall event basically ended at 21:00 UTC. Throughout the period of the extreme rainfall event on 21 July 2012 between 09:00 UTC and 21:00 UTC in Beijing, the orography played an important role in enhancing and focusing the spatial and intensity distribution of rainfall.
The total daily rainfall amounts for the 21-22 July 2012 is shown in Fig. 6. From 09:00 UTC on 21 July to 00:00 UTC on 22 July, the extreme rainfall event lasted for $16 \mathrm{~h}$, and the average daily rainfall was $170 \mathrm{~mm}$ in the whole city and $215 \mathrm{~mm}$ in the urban area, the maximum rainfall since 1951. Compared with the rainfall of the same period, the average monthly rainfall of July in Beijing was $156.7 \mathrm{~mm}$ for the past $30 \mathrm{yr}$, and it was $291 \mathrm{~mm}$ in July 2012, which an increase of $75 \%$ for the same period; on 21-22 July, the rainfall amount was $73.9 \%$ of the total monthly rainfall in July 2012 .

According to the rainfall data of these twelve maps, we calculate the hourly and accumulative rainfall of the eight affected districts on 21-22 July 2012, between 09:00 UTC and 21:00 UTC (Figs. 7 and 8). By analyzing the rainfall data of these two figures, the hourly rainfall of all affected districts reached the maximum within an hour after the extreme rainfall event occurred. Particularly in Fengtai, Shijingshan and Chaoyang, the maximum hourly rainfall exceeded $50 \mathrm{~mm} \mathrm{~h}^{-1}$ from 11:00 UTC on 21 July 2012. The accumulative rainfall of Fengtai, Daxing, Shijingshan, Chaoyang, Fangshan and Tongzhou exceeded $100 \mathrm{~mm}$ within an hour after the extreme rainfall event occurred, which achieved the standard of the red rainstorm warning (the most serious level of rainstorm warning). So this extreme rainfall event has been defined as a catastrophic event with suddenness and high-intensity rainfall.

Results from the analysis of the characteristic of rainfall indicate that the sudden and high-intensity rainfall are the main reasons for inducing high economic losses and a huge number of human casualties in this extreme rainfall event. Many researchers define the suddenness of the extreme rainfall event in reference to rain occurrence (response time) or, more directly, in terms of the time to reach the maximum rainfall (Schwein, 1996; Morrow, 1997; Montz, 2001; Falconer et al., 2009). A sudden rainstorm event means the rainfall may reach a floodplain within minutes to a few hours after the event occurs, leaving little or no time for early warning and emergency preparedness, which leads to more 


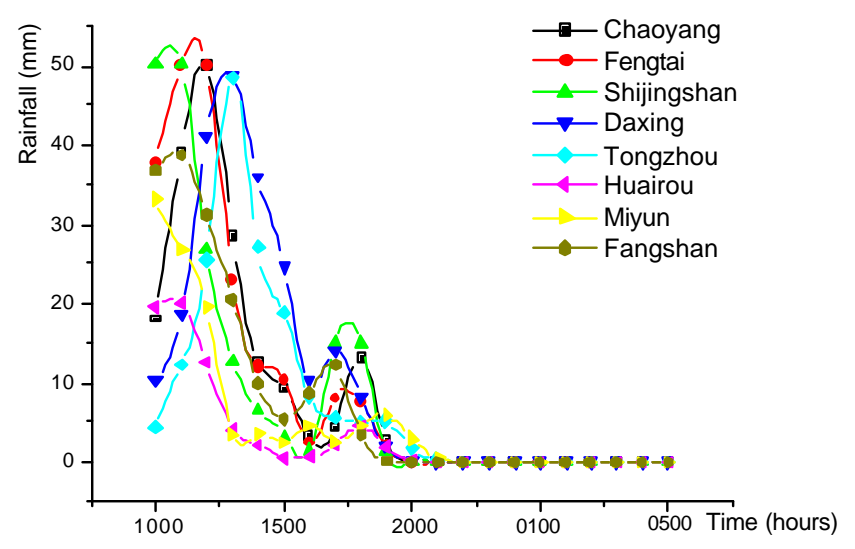

Fig. 7. Hourly rainfall of eight mainly affected districts between 09:00 UTC and 21:00 UTC on 21-22 July 2012.

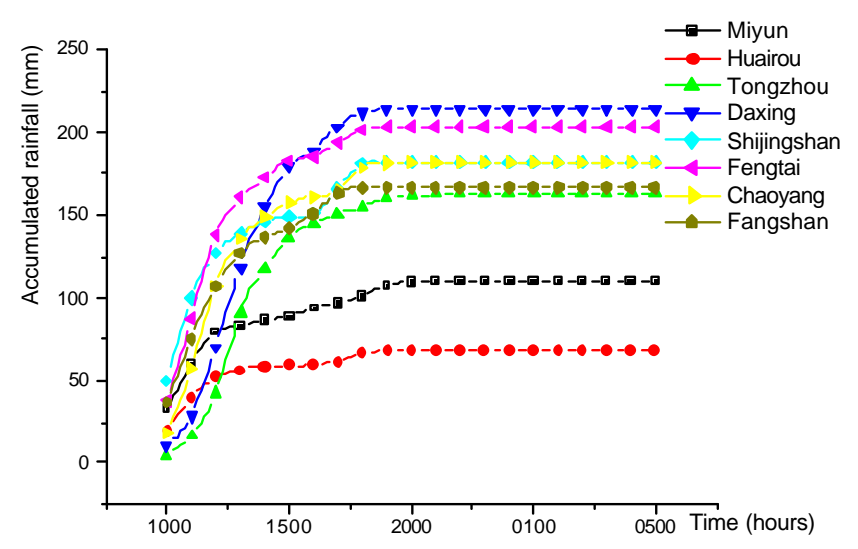

Fig. 8. Accumulated rainfall of eight mainly affected districts between 09:00 UTC and 21:00 UTC on 21-22 July 2012.

populations facing higher risk (Creutin and Borga, 2003; Fothergill and Peek, 2004; Merz et al., 2010).

In this rainfall event, approximately $49 \%$ of victims were killed in the Fangshan district. Besides the impact of the characteristics of rainfall, the topography of Beijing is aanother reason to explain that the victims were heavily concentrated in Fangshan district. Fangshan district is located in the mountain areas in western Beijing, which is surrounded by the mountains and belongs to the low-lying areas. So the flash floods and debris flows are often occurred in this district, which makes it become the geological disaster-prone areas in Beijing. Beijing is surrounded by mountains on three sides, which is conducive to the uplift movement of the warm and humid air, but not horizontal diffusion. Those gathered warm and humid air will be developed into a heavy rainfall in the western of Beijing with the effect of southwesterly airstream. Due to the impact of heavy rainfall and unstable geological conditions, the mudslides and flash floods occurred in Fangshan district on 21-22 July 2012, which killed 38 persons.

\subsection{Analysis of the distribution and characteristics of victims}

Classifying the victims by gender and age characteristics, we find $58.33 \%$ of the total victims are males, $70 \%$ of the total victims are adults, $11 \%$ of the total victims are children and $19 \%$ are elderly people. Compared with the distribution of gender and age in the district population before this extreme rainfall event (Table 1), we can find the "vulnerable group " in this extreme rainfall event (Figs. 9 and 10). By analyzing these two figures, the result offers a new perspective in identifying the "vulnerable group" in this extreme rainfall event. Many studies have shown that the vulnerability of people mostly relate to factors such as age, disability, ethnicity, income, family structure and social networks, housing and the built environment (Blaikie et al., 1994; Granger, 2003). Sivell et al. (2008) suggest that those aged over $75 \mathrm{yr}$ are considered a vulnerable sector of a population. Many nongovernmental organizations and other development institutions define "vulnerable groups" as women, children, elderly people, and the like. But in this extreme rainfall event, the percentage of male victims exceeds the percentage of males in seven affected districts (the average percent of males in the eight affected districts is $51.7 \%$, while the average percent of male victims in this extreme rainfall event is $58.33 \%$ ) (Fig. 9). Similarly, the percentage of adult victims overall exceeds the percentage of adult in the eight affected districts (the average percent of adults of the eight affected districts is $64.79 \%$, while the average percent of adult victims in this extreme rainfall event is $70 \%$ ). But most of the percentage of child and elderly victims are lower than the percentage of children and elderly people in the eight affected districts (the percentage of children and elderly people of the eight affected districts are $14.25 \%$ and $20.97 \%$, respectively, while the average percent of child victims and elderly victims in this extreme rainfall event are $11.67 \%$ and $18.33 \%$, respectively) (Fig. 10).

Different people will be vulnerable to different hazards in differing degrees, although there may will be households which, if they are vulnerable to one type of hazard, are likely to be vulnerable to others too (Wisner, 2003). The reason for the gender and age distribution of victims in the extreme rainfall event may be affected by the death circumstances, the cause of death and the time of the extreme rainfall event. According to the statistical data from World Bank (2005), $85 \%$ of the victims were killed outside in the extreme rainfall event. The analysis of death circumstances of this extreme rainfall event shows that $90 \%$ of victims were killed outside the home (e.g. in the village, on the lawn, under the bridge, on the river bank, on the highway, on the street, etc), and $77 \%$ of victims were killed in a drowning accident (Table 2). Time is "of the essence" as the understanding of disasters lies in the time the disaster occurs (the day or night) and the stage of the impact of the disaster after the hazard has occurred. The day of the week (particularly market days, rest, festival or holy 


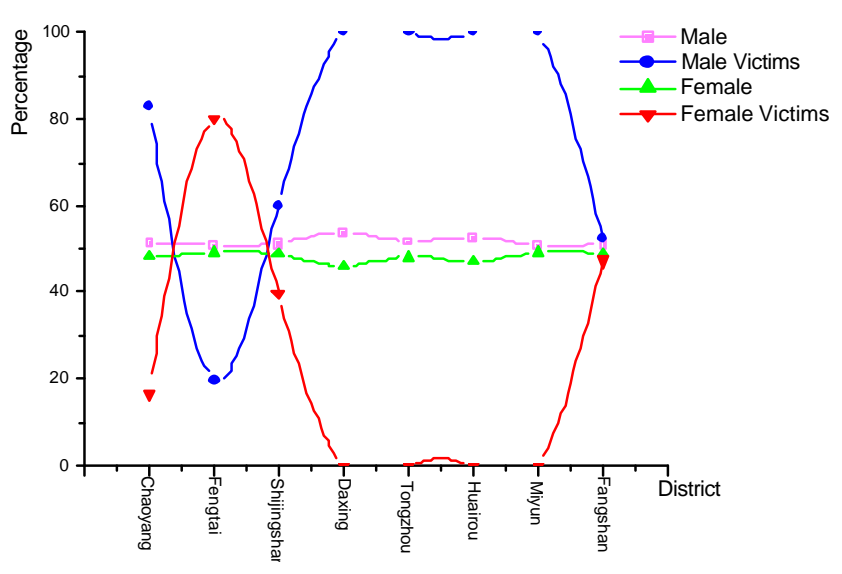

Fig. 9. The gender distribution of population and victims in the eight affected districts.

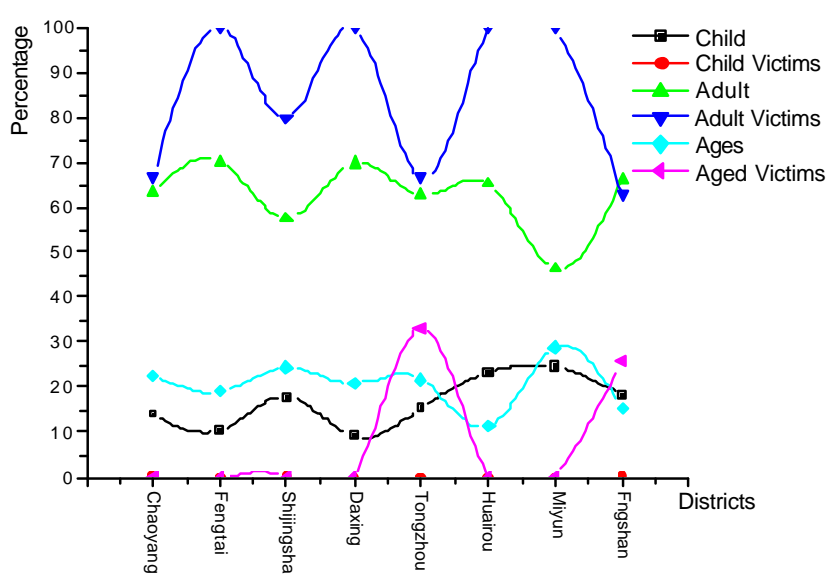

Fig. 10. The age distribution of population and victims in the eight affected districts.

days) is also relevant in terms of possible concentrations of people in space and time. In this study, the extreme rainfall event occurred at 09:00 on Saturday, and most of the victims were killed from 09:00 to 15:00. During this time, most young people or families went out to spend the weekend, in contrast, most elderly people were at home or inside buildings. In addition, this is the tourist season in Beijing; large numbers of tourists came to Beijing for holiday, and $80 \%$ of these tourists are young and middle-aged adults, which may be another reason that the "vulnerable groups" are males and adults in the extreme rainfall event during 21-22 July 2012 in Beijing.

\subsection{Analysis of the effects of the extreme rainfall parameters on the human vulnerability of victims with different characteristics}

Three linear regression models show a detailed quantitative analysis of the impact of each extreme rainfall parameter and their combined effects on human vulnerability of different types of populations (Table 4). In order to describe the influence degree of each extreme rainfall parameter on victims with different characteristics more clearly, we use dark gray to indicate a high level of impact, light gray for medium and white for low. An asterisk (*) symbol marks the most significant impact of each extreme rainfall parameter index on victims of all types of victims. The data of the extreme rainfall parameters which are used in 3 models are all standardized (by dimensional analysis, a dimensionless quantity is a quantity without an associated physical dimension) to eliminate the impact of the different unit of each parameter.

\subsubsection{Model 1 the impact of each extreme rainfall parameter on victims in 3 different age groups}

Model 1 (Table 4) and Fig. 11 show the impact of extreme rainfall parameters on victims with different ages. In model 1-1 (child victims), the influence of TP, MHP, AHP on the child victims are larger than other extreme rainfall parameters. Thus the vulnerability of children to the extreme rainfall event has a very significant relationship with rainfall event. In model 1-2 (adult victims) and model 1-3 (elderly victims), the influence of TP, AHP and $\mathrm{DP}_{10}$ on the adult and elderly victims are larger than other extreme rainfall parameters. As such, the effects of the rainfall event and duration have more impact on the vulnerability of adult and elderly victims. In model $1-2$, the coefficients of each extreme rainfall parameter is larger than the coefficients in other two models. For the extreme rainfall parameters with significant influence, the TP coefficient is 6 times larger than that in model 1-1, and 2 times that in model 1-3; the AHP coefficient is 4 times larger than that in model $1-1$, and 3 times that in model $1-3$; the $\mathrm{DP}_{10}$ coefficient is 5 times larger than that in model $1-1$, and 3 times that in model $1-1$. This provides an indication that all of the extreme rainfall parameters have a greater influence on adult victims than the remaining two models. The adult victims are more susceptible to the change of the extreme rainfall parameters than children and elderly victims. Particularly in model $1-2, \mathrm{TP}_{50}, \mathrm{TP}$, and $\mathrm{DP}_{10}$ have the most significant impact on adult victims of all types of victims (including child, elderly, male and female victims). So the adult victims are most susceptible to the change of $\mathrm{TP}_{50}, \mathrm{TP}, \mathrm{DP}_{10}$ than other types of victims.

\subsubsection{Model 2 the impact of each extreme rainfall parameter on victims in 2 different gender groups}

Model 2 (Table 4) and Fig. 12 show that the impact of each extreme rainfall parameter on victims in different gender groups. For the two models (male and female), the influence of TP, AHP and $\mathrm{DP}_{10}$ on the male and female victims are larger than other extreme rainfall parameters. So the vulnerability of male and female to the extreme rainfall event have a very significant relationship with the rainfall event and 
Table 4. Linear regression models of the impact of each extreme rainfall parameter on victims according to age groups (model 1), gender (model 2) and total number of victims (model 3).

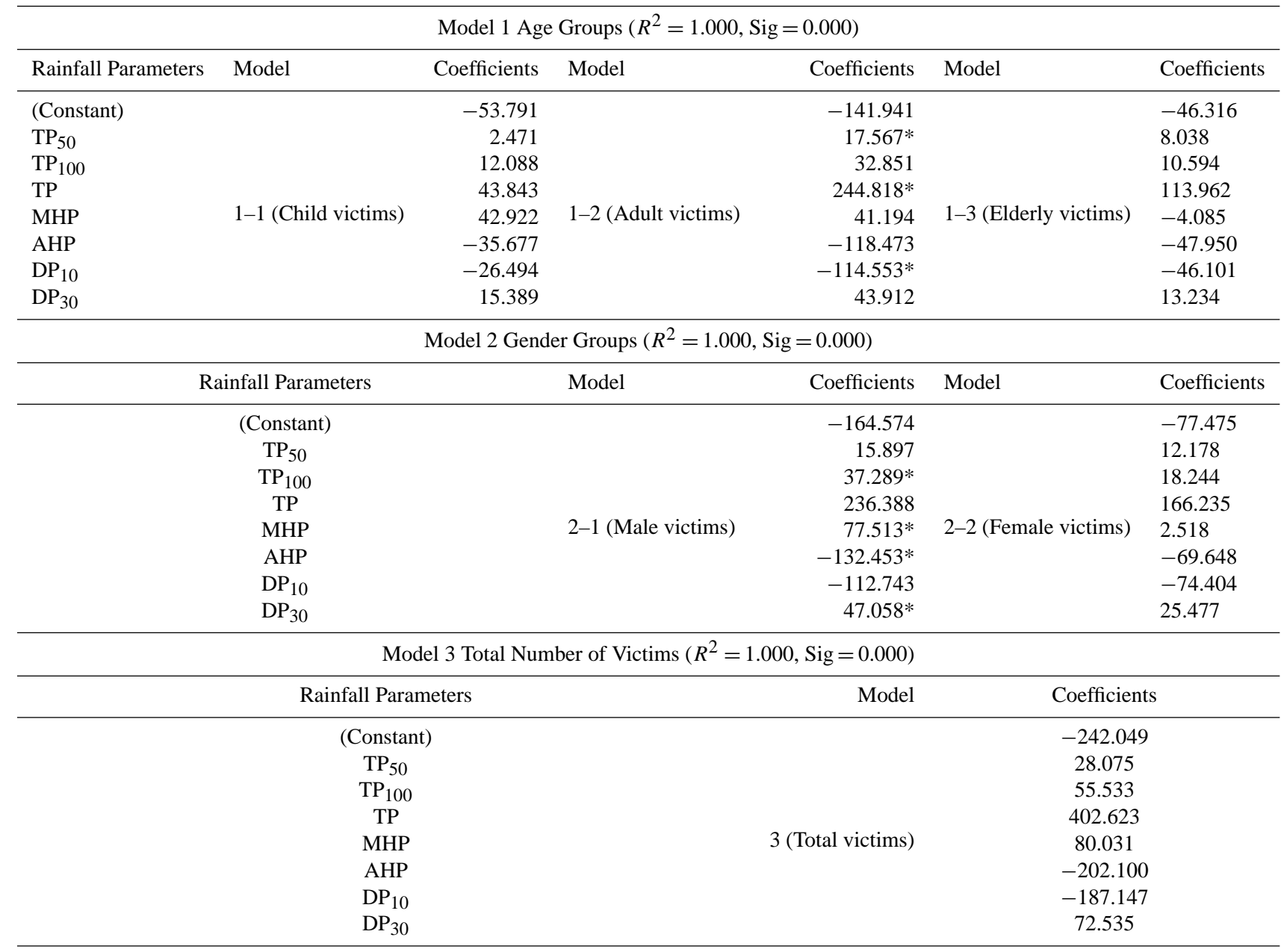

duration. Comparing model 2-1 (male victims) with model 2-2 (female victims), the result supports the notion proposed in Sect. 4.1 that the "vulnerable group" is a group of people who are more susceptible to the change of the extreme rainfall parameters. In model $2-1$, the coefficients of each extreme rainfall parameter is larger than the coefficients in model 2-2, particularly $\mathrm{TP}_{100}$, MHP, and AHP, which have the most significant impact on male victims of all types of victims (including child, adult, elderly, female victims). It is the the reason that the the number of male victims are higher than female victims. It also demonstrates the reason that the vulnerability of males is generally higher than females in this extreme rainfall event.

\subsubsection{Model 3 the impact of each extreme rainfall parameter on the total victims}

As a comparative model, model 3 (Table 4) and Fig. 13 show the impact of each extreme rainfall parameter on the total victims. According to this model, TP, AHP and DP10 show a much stronger relation to the total victims. TP especially has a significant influence on the total victims, with each unit of $\mathrm{TP}$ extending in the process of the extreme rainfall event, and the number of victims increasing by a multiplicative factor of 402.623. So the total rainfall and the average hourly rainfall, which respectively characterize the depth and severity of the extreme rainfall event, is the decisive factors of the total victims. In addition to this, rainfall duration, which represented the lasting time of the extreme rainfall event, also plays an important role in affecting the total victims. So the total victims are more susceptible to the rainfall event and duration than other physical characteristics of extreme rainfall events.

Linear regression models explain the impact of each extreme rainfall parameter on victims with different characteristics. Inspection of model simulation shows that the quality of these six statistical models are supported by a $t$ test which described the quality of fit criteria with significance values above 0.05 , and the coefficient of determination $R^{2}$, which describes how well a regression line fits a dataset. With the accepted quality of fit criteria $\left(R^{2}=1.000, \mathrm{Sig} .=0.000\right)$, 


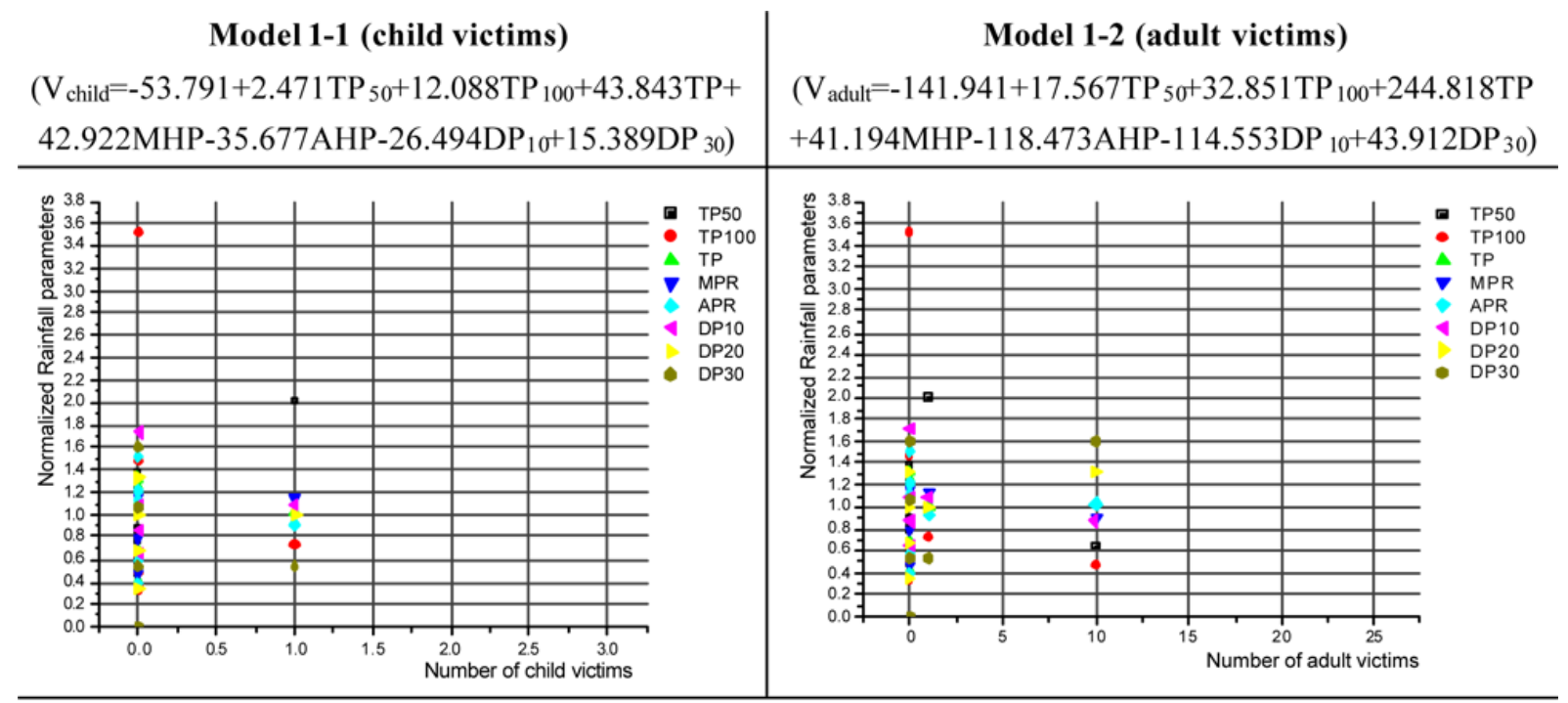

Model 1 -3 (elderly victims)

$\left(\mathrm{V}_{\text {elderly }}=-46.316+8.038 \mathrm{TP}_{50}+10.594 \mathrm{TP}_{100}+113.962 \mathrm{TP}-4.085 \mathrm{MHP}-47.950 \mathrm{AHP}-46.101 \mathrm{DP}_{10}+13.234 \mathrm{DP}_{30}\right)$

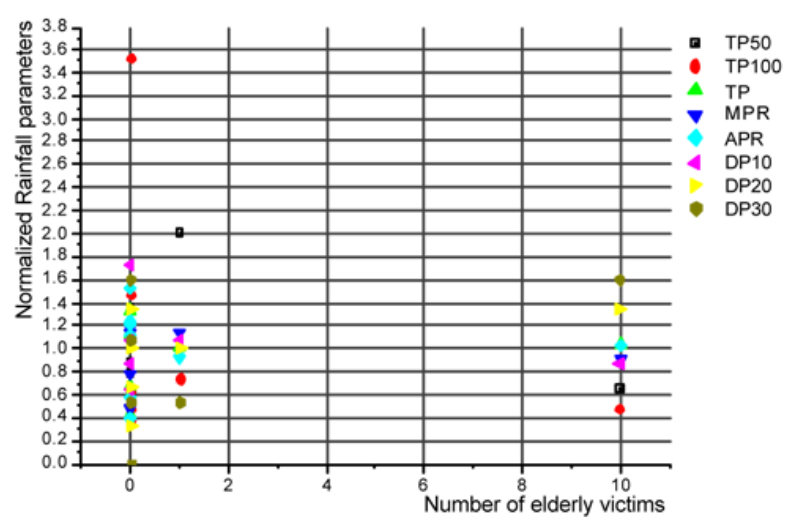

Fig. 11. The relationship between each extreme rainfall parameter and victims in 3 different age groups.
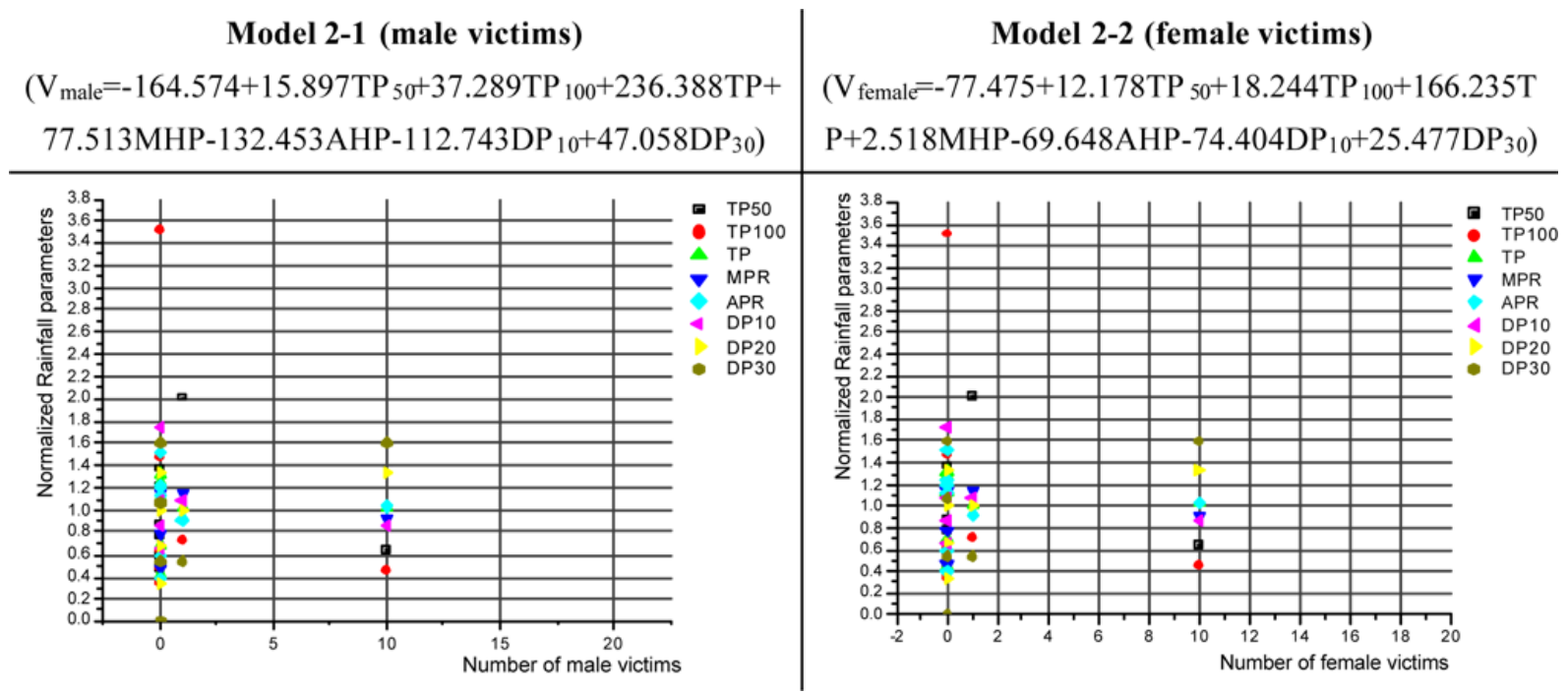

Fig. 12. The relationship between each extreme rainfall parameter and the number of male victims of the eight affected districts. 


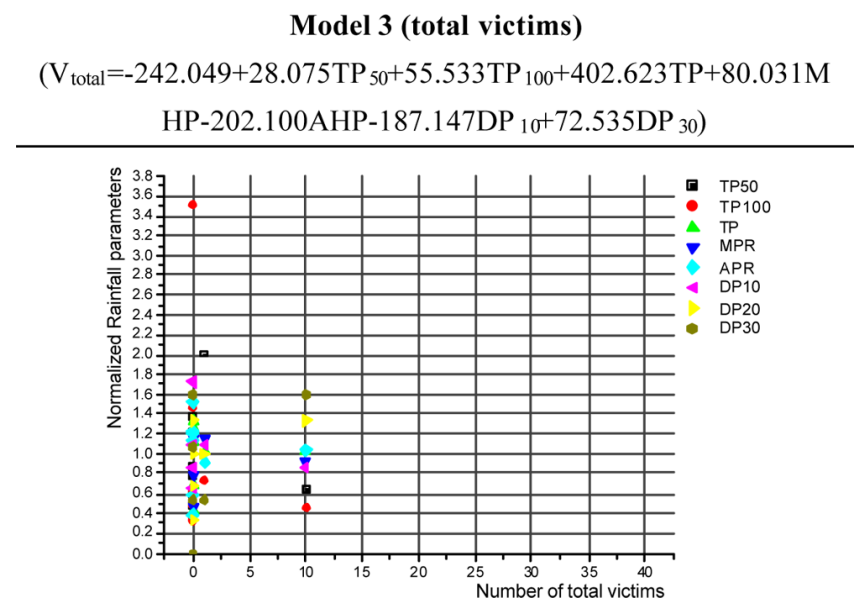

Fig. 13. The relationship between each extreme rainfall parameter and the total victims.

these six statistical models were all supported so that these independent variables delivered a valid explanation. These models could therefore be the appropriate analysis measures to explain the relationship between each extreme rainfall parameter and victims with different characteristics.

\section{Discussion}

In this paper, we use the linear regression model to quantitatively analyze the impact of extreme rainfall parameters on different types of victims. In these three models, the relevance of most extreme rainfall parameters with victims are similar but one is different in model $1-3 . \mathrm{TP}_{50}, \mathrm{TP}_{100}, \mathrm{TP}$, MHP, are $\mathrm{DP}_{30}$ are positively associated with victims. AHP and $\mathrm{DP}_{10}$ are negatively associated with victims. The main difference is that MHP is negatively associated with elderly victims in model 1-3 (Table 3 and Fig. 10). This result shows, as expected, that higher rainfall intensity and longer rainfall duration would lead to more victims. But the relevance of response time $\left(\mathrm{TP}_{50}\right.$ and $\left.\mathrm{TP}_{100}\right)$ with victims contradicts our previous assumptions that response time should be negatively associated with victims. The interpretation of this relation can not be obtained from the data presented in this paper. For the chosen three groups of extreme rainfall parameters, the variables TP, AHP and $\mathrm{DP}_{10}$ can be considered to be a valuable contribution for all types of victims. Especially TP has a much higher influence on victims than other 2 variables. This result supports a general notion that the rainfall event and duration, which are the physical factors to determine the risk of extreme rainfall event (DEFRA and EA, 2006), could be used as a key index to affect the number of victims in an extreme rainfall event. It demonstrates that the extreme rainfall may occur more severely due to the increasing duration of high-intensity rainfall, even causing local flooding and mudslide. Although the definition of human vulnerability to the extreme rainfall event is sometimes understood simply as their ability to respond to and withstand the extreme rainfall event, the physical characteristics of an extreme rainfall event has a very significant influence on it. In model 1-2 and model 2-1, the result proves that the adult and male victims are more susceptible to the change of the extreme rainfall parameters than other types of victims, because males were the most exposed population during the day and hours of the rainfall event. The extreme rainfall event occurred on 21-22 July in Beijing, which is a 1-in-60 yr event with the physical characteristics of high-intensity rainfall and long duration, and led to more males and adults being killed. Besides the impact of the characteristic of rainfall, the analysis of the distribution and characteristics of victims shows that more adults and males were killed may be related with the death circumstances, the cause of the death and the time of this extreme rainfall event. More than $90 \%$ victims were killed outside home (77\% were killed in the drowning accident) between 09:00 and 15:00. During this time, there is a great chance for the adults and males to be outside the home for working, traveling and business. The combination of the suddenness and high-intensity rainfall and the distribution of people when the extreme rainfall event occurs can justify why adults and males are the "vulnerable group" in this extreme rainfall event.

\section{Conclusions}

As a general conclusion, the study presented here shows the temporal and spatial characteristics of rainfall in the extreme rainfall event on 21-22 July 2012 in Beijing, and its impact on the vulnerability of populations with different characteristics (age, gender and total number of victims). Firstly, we use the daily and hourly rainfall data from the Beijing meteorological stations and the Surface Weather Observation Stations to reconstruct the process and distribution of the rainfall during the extreme rainfall event, and demonstrate the characteristics of the extreme rainfall event based on the geographical location, the rainfall distribution, and the hazard characterization of various affected regions. Secondly, we analyze the characteristics of the victims, including their gender, age, the causes of death, the distribution and location of victims in the eight affected regions. The result of our study offers a new perspective in identifying the "vulnerable groups", which is different from the traditional research about the characteristics of vulnerable populations in disasters. Our statistical data shows that the male and adult victims are more vulnerable than female, children and elderly victims in this extreme rainfall event. The result is related to the characteristics of rainfall, the topography of affected districts, the time this extreme rainfall event occurred, and the distribution and location of victims. Finally, our study makes a significant contribution to understand the relationship between the rainfall parameters and victims with different characteristics. Through building several linear regression models, we find that the gender and age distribution of victims in this 
extreme rainfall event is affected by the rainfall intensity and duration in the affected areas. The male and adult victims are more susceptible to the change of the physical characteristics of rainfall than other types of victims in this extreme rainfall event, which made males and adults be the "vulnerable group" in this extreme rainfall event. In conclusion, the results of our study can provide a new perspective for stakeholders to identify the population at risk and select the extreme rainfall parameters which could affect human vulnerability significantly in an extreme rainfall event, and develop a mitigation approach to reduce casualties and economic losses caused by an extreme rainfall event.

Acknowledgements. This study was funded by CRSRI Open Research Program (CKWV2012300/KY) in the framework of the project entitled "The Research on the Dynamic Evaluation of city Flooding Vulnerability and Early Warning Model in the Yangtze River Basin". We are thankful to editorial support(Anne Brekerbohm) and two reviewers (Sven Fuchs and Susana Pereira) for the improvement of the manuscript.

Edited by: V. Tofani

Reviewed by: S. Pereira, S. Fuchs, and two anonymous referees

\section{References}

Adelekan, I. O.: A Survey of Rainstorm as Weather Hazards in Southern Nigeria, Environmentalist, 20, 33-39, 2000.

ADPC and UNDP (Asian Disaster Preparedness Center and United Nations Development Programme: Integrated flood risk management in Asia, Bangkok, ADPC and UNDP, 2005.

Anderson, W. A.: Bringing children into focus on the social science disaster research agenda, Int. J. Mass Emerg. Disast., 23, 159_ $175,2005$.

Barnett, J., Lambert, S., and Fry, I.: The hazards of indicators: insights from the environmental vulnerability index, Ann. Assoc. Am. Geogr., 98, 102-119, 2008.

Barroca, B., Bernardara, P., Mouchel, J. M., and Hubert, G.: Indicators for identification of urban flooding vulnerability, Nat. Hazards Earth Syst. Sci., 6, 553-561, doi:10.5194/nhess-6-5532006, 2006.

Basher, R. and Briceño, S.: Climate and disaster risk reduction in Africa, Climate change and Africa, 271-283, 2005.

Beniston, M.: Trends in joint quantiles of temperature and rainfall in Europe since 1901 and projected for 2100, Geophys. Res. Lett. 36, L07707, doi:10.1029/2008GL037119, 2009.

Blaikie, P., Cannon, T., Davis, I., and Wisner, B.: At Risk: Natural Hazards, People's Vulnerability, and Disasters, London, Routledge, 1994.

Beniston, M. and Stephenson, D. B.: Extreme climatic events and their evolution under changing climatic conditions, Global Planet. Change, 44, 1-9, 2004.

Bodini, A. and Cossu, Q. A.: Vulnerability assessment of CentralEast Sardinia (Italy) to extreme rainfall events, Nat. Hazards Earth Syst. Sci., 10, 61-72, doi:10.5194/nhess-10-61-2010, 2010 .
Boruff, B. J. and Cutter, S. L.: The environmental vulnerability of Caribbean island nations, Geogr. Rev., 97, 24-45, 2007.

Bosher, L., Andrew, D., Patricia, C., and Jacqueline G.: Built-in resilience to disasters: a preemptive approach, Eng. Construct. Architect. Manage., 14, 434-446, 2007.

Burton, I., Kates, R. W., and White, G. F.: The environment as hazard, The Guilford Press, New York, 1993.

Cannon, T.: Gender and climate hazards in Bangladesh, Gender Develop., 10, 45-50, 2002.

Cardona, O. D.: System of Indicators for disaster risk management, Manizales/Washington, DC, Instituto de Estudios Ambientales IDEA and Inter American Development Bank, 2005.

Church, J. A., Woodworth, P. L., Aaurup, T., and Wilson, W. S.: Understanding sea-level rise and variability, Wiley-Blackwell, Singapore, 2010.

Cislaghi, M., De Michele, C., Ghezzi, A., and Rosso, R.: Statistical assessment of trends and oscillations in rainfall dynamics: analysis of long daily Italian series, Atmos. Res., 77, 188-202, 2005.

Creutin, J. D. and Borga, M.: Radar hydrology modifies the monitoring of flash flood hazard, Hydrol. Process., 17, 1453-1456, 2003.

Cutter, S. L., Mitchell, J. T., and Scott., M. S.: Revealing the vulnerability of people and places: A case study of georgetown county, south carolina, Ann. Assoc. Am. Geogr., 90, 713-737, 2000.

DEFRA and EA: R\&D outputs: Flood risks to people, Phase 2, FD2321/TR1 The flood risks to people methodology, London: Department for Environment Food and Rural Affairs and the Environment Agency, 2006.

Duchon, J.: Interpolation des fonctions de deux variables suivant le principe de la flexion des plaques minces, Revue Francaise d'Automique, Informatique, Recherche Operationnelle (RAIRO) Analyse Num., 10, 5-12, 5012, 1976.

Dutta, D., Wright, W., and Philip, R.: Synthetic impact response functions for flood vulnerability analysis and adaptation measures in coastal zones under changing climatic conditions: a case study in Gippsland coastal region, Australia, Nat. Hazards, 59, 967-986, 2011.

Enarson, E. and Morrow, B. H.: The gendered terrain of disaster, International Hurricane Center, 1998.

Falconer, R. H., Cobby, D., Smyth, P., Astle, G., Dent, J., and Golding, B.: Pluvial flooding: New approaches in flood warning, mapping and risk management, J. Flood Risk Manage., 2, 198-208, 2009.

Falconer, R. H., Cobby, D., Smyth, P., Astle, G., Dent, J., and Golding, B.: Pluvial flooding: New approaches in flood warning, mapping and risk management, J. Flood Risk Manage., 2, 198-208, 2009.

Fernando, A. D.: Urbanisation and flood vulnerability in the periurban interface of Mexico City, Disasters, 31, 477-494, 2007.

Fothergill, A. and Peek, L. A.: Poverty and Disasters in the United States: A Review of Recent Sociological Findings, Nat. Hazards, 32, 89-110, 2004.

Fuchs, S.: Susceptibility versus resilience to mountain hazards in Austria - paradigms of vulnerability revisited, Nat. Hazards Earth Syst. Sci., 9, 337-352, doi:10.5194/nhess-9-337-2009, 2009.

Granger, K.: Quantifying Storm Tide Risk in Cairns, Nat. Hazards, 30, 165-185, 2003. 
Groisman, P. Y., Knight, R. W., Karl, T. R., Easterling, D. R., Sun, B., and Lawrimore, J.: Contemporary changes of the hydrological cycle over the contiguous United States: trends, J. Hydrometeorol, 5, 64-85, 2004.

Hewitt, K.: Regions of Risk: A Geographical Introduction to Disasters, Geo-Spatial Technologies in Urban Environments, 1997.

Honghai, Q. and Altinakar, M. S.: A GIS-based decision support system for integrated flood management under uncertainty with two dimensional numerical simulations, Environ. Model. Softw., 26, 817-821, 2011.

Huntington, T. G.: Evidence for intensification of the global water cycle: review and synthesis, J. Hydrol., 319, 83-95, 2006.

Hutchinson, M. F.: On thin plate splines and kriging, Comput. Sci. Stat., 25, 55-62, 1993.

Hutchinson, M. F. and Gessler, P. E.: Splines-more than just a smooth interpolator, Geoderma, 62, 45-67, 1994.

Ibidun, O. A.: Vulnerability assessment of an urban flood in Nigeria: Abeokuta flood 2007, Nat. Hazards, 56, 215-231, 2011.

Intergovernmental Panel on Climate Change (IPCC): Climate Change 2001: Impacts, Adaptation, and Vulnerability, Contribution of Working Group II to the 3rd Assessment Report of the IPCC, Cambridge: Cambridge University Press, 2001.

Isabelle, R., Jean-Dominique, C., Sandrine, A., and Céline, L.: Human exposure to flash floods - Relation between flood parameters and human vulnerability during a storm of September 2002 in Southern France, J. Hydrol., 361, 199-213, 2008.

Kappes, M. S., Papathoma-Köhle, M., and Keiler, M.: Assessing physical vulnerability for multi-hazards using an indicator-based methodology, Appl. Geogr., 32, 577-590, 2012.

Kaźmierczak, A. and Gina, C.: Surface water flooding risk to urban communities: Analysis of vulnerability, hazard and exposure, Lands. Urban Plan., 103, 185-197, 2011.

Kelly, P. M. and Adger, W. N.: Theory and practice in assessing vulnerability to climate change and facilitating adaptation, Climatic Change, 47, 325-352, 2000.

Kelsch, M., Caporali, E., and Lanza, L. G.: Hydrometeorology of flash floods, Coping with Flash Floods, 77, 19-35, 2001.

Kienberger, S: Spatial modelling of social and economic vulnerability to floods at the district level in Buzi, Mozambique, Nat. Hazards, 64, 2001-2019, 2012.

Lasletta, G. M.: Kriging and Splines: An Empirical Comparison of their Predictive Performance in Some Applications, J. Am. Stat. Assoc., 89, 391-400, 1994.

Lindley, S. J., Handley, J. F., Theuray, N., Peet, E., and McEvoy, D.: Adaptation strategies for climate change in the urban environment-assessing climate change related risk in UK urban areas, J. Risk Res., 9, 543-568, 2006.

Linnekampa, F., Koedamb, A., and Baud, I. S. A.: Household vulnerability to climate change: Examining perceptions of households of flood risks in Georgetown and Paramaribo, Habitat Int., 35, 447-456, 2011.

Luna, T., Rocha, A., Carvalho, A. C., Ferreira, J. A., and Sousa, J.: Modelling the extreme precipitation event over Madeira Island on 20 February 2010, Nat. Hazards Earth Syst. Sci., 11, 24372452, doi:10.5194/nhess-11-2437-2011, 2011.

Machefert, S. E. and Dise, N. B.: Hydrological controls on denitrification in riparian ecosystems, Hydrol. Earth Syst. Sci., 8, 686-694, doi:10.5194/hess-8-686-2004, 2004.
McEntire, D. A.: Why vulnerability matters: Exploring the merit of an inclusive disaster reduction concept, Disaster Prevent. Manage., 14, 206-222, 2005.

Mechler, R., Hochrainer, S., Linnerooth-Bayer, J., and Pflug, G.: Public sector financial vulnerability to disasters: The IIASA CATSIM model, United Nations University Press, 2006.

Meehl, G. A., Stocker, T. F., Collins, W. D., Friedlingstein, P., Gaye, A. T., Gregory, J. M., Kitoh, A., Knutti, R., Murphy, J. M., Noda, A., Raper, S. C. B., Watterson, I. G., Weaver, A. J., and Zhao, Z. C.: Global climate projections, in: Climate change 2007: the physical science basis, edited by: Solomon, S., Qin, D., Manning, M., Chen, Z., Marquis, M., Averyt, K. B., and Tignor, M., Contributions of working group to the fourth assessment report of the intergovernmental panel on climate change, Cambridge University Press, 2007.

Merz, B., Thieken, A. H., and Gocht, M.: Flood risk mapping at the local scale: concepts and challenges, Adv. Natural Technol. Hazards Res., 25, 231-251, 2007.

Merz, B., Hall, J., Disse, M., and Schumann, A.: Fluvial flood risk management in a changing world, Nat. Hazards Earth Syst. Sci., 10, 509-527, doi:10.5194/nhess-10-509-2010, 2010.

Meyer, V., Scheuer, S., and Haase, D.: A multicriteria approach for flood risk mapping exemplified at the Mulde river, Germany, Nat. Hazards, 48, 17-39, 2009.

Miceli, R., Sotgiu, I., and Settanni, M.: Disaster preparedness and perception of flood risk: A study in an Alpine valley in Italy, J. Environ. Psychol., 28, 164-173, 2008.

Millennium Ecosystem Assessment (MA): Ecosystems and Human Wellbeing: Synthesis, ishington DC, Island Press, 2005.

Montz, B. E.: Assessing the effects and effectiveness of flash flood mitigation strategies, in: Coping with Flash Floods, Kluwer Academic Publishers, Dordrecht, Nato Science Series 2Environmental security, 77, 123-134, 2001.

Montz, B. E. and Gruntfestb, E.: Flash flood mitigation: recommendations for research and applications, Global Environ. Change, 4, 15-22, 2002.

Morrow, B. H.: Stretching the Bonds: the Families of Andrew', in: Hurricane Andrew: Ethnicity Gender and the Sociology of Disasters, edited by: Peacock, W. G., Morrow, B. H., and Gladwin, H.m Routledge, London, 141-170, 1997.

Pelling, M.: Measuring Vulnerability to Urban Natural Disaster Risk, Open House International, Special Issue on Managing Urban Disasters, 31, 125-132, 2005.

Pfister, N.: Community response to flood warnings: the case of an evacuation from Grafton, March, 2001, Aust. J. Emerg. Manage., 17, 19-29, 2002.

Rohde, D.: Tsunami's Cruellest Toll: Sons and Daughters Lost, New York Times, 7 January, A1, 2005.

Schwein, N. O.: The Effect of Quantitative rainfall Forecasts on River Forecasts, NOAA Technical Memorandum NWS-CR-110, National Weather Service, Washington DC, 1996.

Sivell, S., Elwyn, G., Gaff, C. L., Clarke, A. J., and Iredale, R.: How Risk is Perceived, Constructed and Interpreted by Clients in Clinical Genetics, and the Effects on Decision Making: Systematic Review, J. Genet. Counsel, 17, 30-63, 2008.

Smith, O. A.: Theorizing Vulnerability in a Globalized World: A Political Ecological Perspective, in: Mapping Vulnerability: Disasters, Development and People, edited by: Bankoff, G., Frerks, G., and Hilhorst, D., London, Earthscan, 10-24, 2004. 
Steffen, W., Turner, B. L., Wasson, R. J., Sanderson, A., Tyson, P., Jager, J., Matson, P., Moore, B., Oldfield, F., Richardson, K., and Schellnhuber, H. J.: Global Change and the Earth System: A Planet Under Pressure, Global Change, 2004.

Thieken, A. H., Muller, M., Kreibich, H., and Merz, B.: Flood damage and influencing factors: New insights from the August 2002 flood in Germany, Water Resour. Res., 41, 1-16, 2005.

Thywissen, K.: Components of Risk-A Comparative Glossary, 2006.

Tollan, A.: Land-use change and floods: what do we need most, research or management? Water Sci. Technol., 45, 183-190, 2002.

Totschnig, R. and Fuchs, S.: Mountain torrents: quantifying vulnerability and assessing uncertainties, Eng. Geol., 155, 31-44, 2013.

Turner, B. L., Kasperson, R. E., Matsone, P. A., James, J. M., Robert, W. Corellg, Christensene, L., Eckley, N., Kasperson, J. X., Luerse, A., Martellog, M. L., Polsky, C., Pulsipher, A., and Schiller, A.: A framework for vulnerability analysis in sustainability science, National Acad. Sci., 100, 8074-8079, 2003.

UNESCO: Landslide hazard zonation: a review of principles and practice, Landslide Hazard Zonation, 1984.

UN-HABITAT: Slums of the World: The Face of Urban Poverty in the New Millennium? Monitoring the Millennium Development Goal, Target 11-World-Wide Slum Dweller Estimation, UN-Habitat, 2003.
UN/ISDR: Living with risk: a global review of disaster review of disaster reduction initiatives. United Nations, 2004.

UNPD (United Nations Population Division): Population division of the department of economic and social affairs, World population prospects: the 2006 revision and world urbanization prospects: the 2007 revision, 2007.

Walker, B., Carpenter, S., Anderies, J., Abel, N., Cumming, G., Janssen, M., Lebel, L., Norberg, J., Peterson, G. D., and Pritchard, R.: Resilience Management in Social-Ecological Systems: a Working Hypothesis for a Participatory Approach, Conservation Ecol., 6, 14-31, 2002.

Weichselgartner, J.: Disaster mitigation: the concept of vulnerability revisited, Disaster Prevent. Manage., 10, 85-95, 2001.

Wisner, B.: Turning Knowledge into timely and Appropriate Action: Reflections on IADB/IDEA Program of Disaster Risk Indicators, IDB/IDEA Program of Indicators for Risk Management, Manizales: National University of Colombia, 2003.

World Bank: Natural Disaster Hotspots: A Global Risk Analysis, Washington DC, The World Bank, Hazard Management Unit, 2005.

Yoon, D. K.: Assessment of social vulnerability to natural disasters: a comparative study, Nat. Hazards, 63, 823-843, 2012. 